\title{
Rainfall Observation and Landslide Warning System.
}

\author{
Kusum Priyanath Jayasinghe \\ Sri Lanka Institute of Information Technology \\ Email Address: kusumbit2016@gmail.com \\ Address: No: 07, Rathnayaka Walawwawatta, Pelawatta Road, Hapugala,Wackwella. \\ City: Galle \\ Country: Sri Lanka - Southern Province \\ Zip code: 80000 \\ DOI: $10.31364 / S C I R J / v 8 . i 3.2020 . P 0320750$ \\ http://dx.doi.org/10.31364/SCIRJ/v8.i3.2020.P0320750
}

\begin{abstract}
Mainly Rainfall observation and Landslide Warning System based on observation of rainfall and determine where the places landslides can be occurred. Mainly the whole system depends on the consideration of rain fall in selected area, by considering all those records if there is high chance to occur a landslide, the system will provide an early warning before it occurs. This research project is conducted under the supervision of Sri Lanka Institute of Information Technology (SLIIT) \& Collaboration of National Building Research Organization (NBRO). NBRO is the main sponsor of this research project. Mainly this project is based on developing a flexible \& scalable solution to reduce the affect of landslide by deploying this system throughout the country dynamically. Also the system automatically detects the high hazard areas which are vulnerable to have landslides in near future and gives a warning message to relevant officials in real time manner.
\end{abstract}

Keywords: NBRO - National Building Research Organization, SLIIT - Sri Lanka Institute of Information Technology

\subsection{INTRODUCTION}

Rainfall Observation \& Landslides Warning System provide Information Technology based solution to observe the rain fall and reduce the affect of landslides. In Sri Lanka there are major areas under seven districts which are always prone to have landslides. By referring that particular record, the proposed research project carries out in Rathnapura District. Basically this is a real time disaster warning system. Which mean the system capable of identify landslide before it occurs \& system automatically provide an early warning.

The main factor which cause to landslides is rain fall. Because of that system mainly consider about the rainfall in selected area. Other geotechnical profiles such as slope, stability \& other details of their tributaries are already provided to the system with corrective measures [3]. To operate the system it expects the rain gauge readings of a particular area in given time. This is automatically provided to the system by using a water sensitive sensor [7]. The system provides with some mathematical equation which can be used to calculate the risk level of occurring landslides. By referring the input values of rain gauges in particular area system will automatically calculate \& check whether if it is exceed the given risk level. If it exceeds the risk level system will provide an early warning to some authorized officers. Then they will be able to identify the risk and perform emergency action to protect civilians' lives.

\subsection{RESEARCH METHODOLOGY}

Mainly this research project provides two main functionalities. As figure 01 shows the first functionality is to capture the dynamic rain falling in Rathnapura district. The second is to identify possible landslides in that area. By developing a real time warning system for landslides hazards areas [4], it provides facility to capture the rain gauge in particular area at any time. System will automatically update by correct rain gauge in particular area at any time. System will automatically update by correct rain gauges levels and the client can see current or previous rainfalls details of particular area through the system. To deploy the system, we select a small area which has high possibility for landslides. This information is provided by NBRO with the aid of their researches about landslides in hazard areas [2]. To capture the rain gauge and send that details to NBRO head office we have to install a device which is capable to do so in Rathnapura district. And also there should be another main system which is capable of receiving the output data of all the devices that are located in Rathnapura district. Then rain gauge capturing devices are situated in a suitable place, the devices will capture the rain gauge details, then it sends those details to the main system which is located in NBRO head office (Colombo) through the internet. Then the system will provide an early warning if there is a possibility to occur a landslide. 


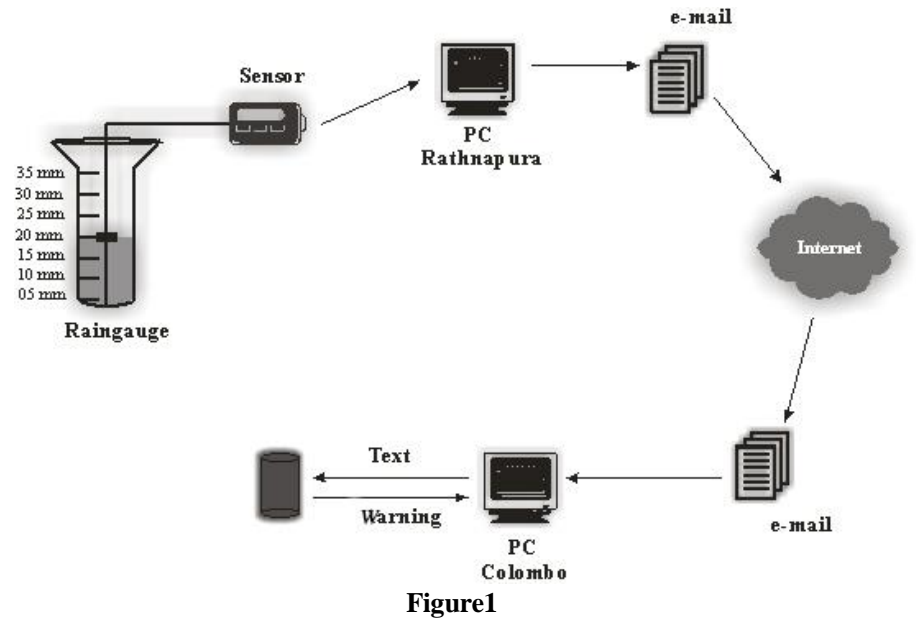

2.1 RESEARCH PROBLEMS.

Today NBRO maintains all the rain gauge details manually. Therefore they have to put fair amount of effort to prepare the documents or annual reports regarding to the rainfall details. Also NBRO doesn't have a proper real time landslide warning system. Landslide play a major disaster role in Sri Lanka. So there is a huge necessary to have real time warning system. In this system consists with the sub stations and main station. Substation PC can receive rain gauge details through the sensor which is connected to the rain gauge. Also it requires two software's which can capture rainfall details through the rain gauge and software for converting parallel port data in to an email. This can be done by using port programming. Finally system needs email filtering software to filter the email to text file. Majority parts of our project are done by automatically by the system.

\subsection{RESEARCH SOLUTIONS.}

At present, in Sri Lanka there is no fully automated landslide warning system and rain fall observation system. The "Rainfall observation and landslide warning System" provide more efficient and reliable solution for reducing the effect of landslide by identifying the landslide before it occurs. According to this research project, the system consists with two major parts. One part is installs in main station's PC which is situated in Colombo (NBRO). The other part is in substation PC which is located in Rathnapura. Inside the Rathnapura district, NBRO identify the major landslide hazard areas which will effect by the landslides in near future. Then deploy the system in that particular area. First deploy the calibrated rain gauge and the water sensitive sensor. As we know rainfall is the major factor that causes to having landslides. Because of that mainly the system considers about the rainfall. Water sensitive sensor is connected with this rain gauge. When the process of increasing water level of the rain gauge the sensor will get activated and it sends those rain gauge details to the substation PC as character values. Then substation's PC sends those details to the main station PC as an email through the internet. In main station's PC retrieves those data and send those data to the database of main station. This database consist with the past rainfall details and identify risk levels of landslides. Then system compares past records with new records and provides a warning if it exceeds the risk level. Inside this whole system process every actions are performed in real time and there are no manual system users. System automatically performs each and every action. There are no any single involvements of the manual system users. All system functions are fully automated.

\subsection{CONCLUSION AND FUTURE WORKS.}

This "Rainfall Observation and Landslides Warning System" is to capture all the rain fall details over the country and observer them through one main location and identify the possible landslide risks and warn before it affects. The system is capable of indicate the currently rain fall situation of the country and provide the report required by NBRO officers according to rainfall (Annual reports). Then the system is also capable of issuing a warning by observing current situation of a relevant area (Landslides). Therefore it is worthwhile to have a system like this for NBRO. In here we consider only one substation. As a future work we can deploy this system through several sub stations which are prone to having landslides. Because of that it will helpful to reduce the effect of landslide all over the country.

\section{REFERENCES.}

[1] p-2007-39,"Inteligent disasters warning system"http://172.16.100.2/4yprojects2007/p-2007-

39/index.html This project proposal describe a implementing a intelligent disasters warning system to tackle the natural disasters. Access date: 04 February 2008

[2] Landslide studies and services division, http://www.nbro.gov.lk/lssd.htm this section describe what are the objectives of having landslide, Saturday,March 5 2008. Access date: 25 January 2008 "Cause

Landslide",http://en.wikipedia.org/wiki/Causes_of_landslide s Landslide, From wikipedia,the free encyclopedia Redirect from Debris avalanche Access date: 05 March 2008. [4] U.S Department of the InteriorU.S Geological survey,"Landslide hazard program", http://landslides.usgs.gov , 28 feb.2008 Access date:29 feb. 2008

[5] U.S. Department of the Interior,U.S. Geological Survey,"Landslide Types and Processors",http://pubs.usgs.gov/fs/2004/3072/fs-20043072.html,fact Sheet 2004-3072,july 2004 Access date: 12 February 2008

[6] R.K Bhandari \& N.Thayalan Proceedings of the National symposium on landslide in Sri Lanka, VOLUME 1,Publish by the Landslide studies and services division of the National Building organization, Colombo $17^{\text {th }}$ March 1994, page no 73-83

[7] By Ministry of science and technology,"Natural diesaster mitigation", http://nrdms.gov.in/natural_disaster.asp , Access date 12 february 2008 
[8] From wikipedia,The Free encyclopedia,"Exposive material", http://en.wikipedia.org/wiki/Explosive_material , 01 march 2008, Access date: 02 march 2008.

[9] From wikipedia,"Types of landslide", http://en.wikipedia.org/wiki/Landslide, This articles provide the description of Types of landslide, $26^{\text {th }}$ February 2008.

Access date: $28^{\text {th }}$ February 2008 